\title{
ДЕЯКІ АСПЕКТИ КВАЛІФІКАЦІЇ ЗЛОЧИНІВ, УЧИНЕНИХ МЕДИЧНИМ АБО ФАРМАЦЕВТИЧНИМ ПРАЦІВНИКОМ ЯК СПЕЦІАЛЬНИМ СУБ' ЄКТОМ ЗЛОЧИНУ
}

Шопіна Ю. О.

\begin{abstract}
У статmі розглянуто деякі аспекти кваліфікації злочинів, передбачених ст. cm. 131, 132, 134, 139-145 Кримінального кодексу України (далі - КК України). Наголошено, що детальний аналіз Особливої частини Кримінального кодексу України дає змогу виділити норми про злочини, що вчиняються медичними та фармацевтичними прачівниками, виявити характер співвідношення норм між собою, а також з іншими нормами про злочини проти життя i здоров'я особи. Зроблено висновок, що під час кваліфікаціі злочину, передбаченого ч. $1 \mathrm{~cm} .140$ КК України, зважаючи на те, що ї диспозиція $\epsilon$ банкетною, необхідно в кожному конкретному випадку встановлювати, які саме професійні обов'язки покладалися на винного та які з цих обов'язків не були виконані взагалі або виконані неналежним чином, а також вимоги яких саме нормативно-правових актів (наказів, інструкцій, вказівок) ним порушено. Кваліфікаційною ознакою злочину, передбаченого ч. $2 \mathrm{~cm} .140$ КК України, $\epsilon$ спричинення діянням тяжких наслідків неповнолітньому.

Ключові слова: кваліфікація злочину, медичний або фармацевтичний працівник, спеціальний суб'єкт злочину, відмежування злочину, конкуренція кримінально-правових норм.
\end{abstract}

В статье рассмотрены некоторые аспекты квалификации преступлений, предусмотренных ст. ст. 131, 132, 134, 139-145 Уголовного кодекса Украины (далее - Ук Украины). Отмечено, что детальный анализ Особенной части Ук Украины позволяет выделить нормы о преступлениях, совершаемых медицинскими и фармацевтическими работниками, выявить характер соотношения норм между собой, а также с другими нормами о преступлениях против жизни и здоровья человека. Сделан вывод, что при квалификации преступления, предусмотренного ч. $1 \mathrm{~cm} .140$ УК Украины, несмотря на то что ее диспозиция является банкетной, необходимо в каждом конкретном случае устанавливать, какие именно профессиональные обязанности возлагались на виновного и какие из этих обязанностей не были выполнены вообще или выполнены ненадлежащим образом, а также требования которых именно нормативно-правовых актов (приказов, инструкций, указаний) им нарушены. Квалифицирующим признаком преступления, предусмотренного ч. 2 cm. 140 УК Украины, является причинение деянием тяжелых последствий несовершеннолетнему.

Ключевые слова: квалификация преступления, медицинский или фармацевтический работник, специальный субъект преступления, отграничения преступления, конкуренция уголовно-правовых норм.

The article deals with some aspects of the qualification of crimes under Art. Art. 131, 132, 134, 139-145 of the Criminal Code of Ukraine. It is emphasized that a detailed analysis of the Particular part of the Criminal Code of Ukraine makes it possible to identify the norms of crimes committed by medical

Шопіна Ю. О., 2019 and pharmaceutical workers, to reveal the nature of their relationship with each other, as well as with other rules on crimes against the life and health of a person. It is concluded that when committing the qualification of the crime under Part 1 of Art. 140 of the Criminal Code of Ukraine, considering that its disposition is a banquet, it is necessary to determine in each case what professional duties were assigned to the guilty and which of these duties were not performed at all or not properly fulfilled, as well as the requirements of which the very normative legal acts (orders, instructions) he violated. The qualifying feature of the crime under Part 2 of Art. 140 of the Criminal Code of Ukraine is causing grievous consequences to a minor. Qualifying crime provided for in Art. 141 of the Criminal Code of Ukraine on the objective side, it should be borne in mind that it has the following features: 1) actions in the form of clinical trials of medicines; 2) consequences in the form of death or other grave consequences; 3) the causal relationship between these actions and the consequences. When qualifying a crime under Art. 143 of the Criminal Code of Ukraine on the objective side it is necessary to establish its following forms: 1) violation of the procedure of transplantation of organs or tissues of a person established by law (Part 1 of Art. 143 of the Criminal Code); 2) seizure from a person by coercion or deception of its organs or tissues (Part 2 of Art. 143 of the Criminal Code); 3) illicit trade in human organs or tissues (Part 4 of Art. 143 of the Criminal Code); 4) participation in transnational organizations engaged in the seizure of human beings by coercion or deception of their organs or tissues for the purpose of their transplantation or illegal trafficking in human organs or tissues (Part 5 of Art. 143 of the Criminal Code). Qualification of the crime provided for in Art. 145 of the Criminal Code of Ukraine on the subjective side requires the establishment of a mixed form of guilt, namely, intent to act and carelessness about its consequences.

Key words: crime qualification, medical or pharmaceutical worker, special subject of crime, delineation of crime, competition of criminal law.

Постановка проблеми та іï актуальність. У кримінально-правовій і криміналістичній літературі неодноразово були спроби виробити критерії кваліфікації злочинів, що вчиняються медичними або фармацевтичними працівниками за різними ознаками, але це питання недостатньо досліджене, тому належить до одного з нагальних.

Аналіз останніх досліджень і публікацій. Дослідженням деяких аспектів кваліфікації злочинів, вчинених медичним або фармацевтичним працівником як спеціальним суб'єктом злочину, займалися такі вчені: В.М. Бурдіна, Ф.Ю. Бердичевський, О.Д. Гринь, О.М. Джужа, О.О. Дудоров, І.О. Нікітіна, А.А. Музика, М.І. Хавронюк, В.Я. Тацій, Г.В. Чеботарьова, В.В. Чернєй, В.Є. Ясиницький.

Проте на даний час існує потреба в досліджені деяких аспектів кваліфікації злочинів, вчинених медич- 
ним або фармацевтичним працівником як спеціальним суб'єктом злочину.

Метою статті $\epsilon$ дослідження деяких аспектів кваліфікації злочинів, передбачених ст. ст. 131, 132, 134, 139-145 КК України.

Виклад основного матеріалу. Для розгляду актуальних у цій статті питань візьмемо за основу класифікацію злочинів, яку пропонує В.А. Журавель. Аналіз складів злочинів, що вчиняються медичними працівниками й передбачені КК і в юридичній літературі, надає змогу виокремити такі юридично значущі ознаки, які слугують основою поділу злочинів на певні класифікаційні групи з відповідними критеріями їі класифікації й розслідування. Так, злочини, що вчиняються медичними працівниками, можуть буди поділені: 1) за сферою реалізації злочинних дій на ті, що вчиняються у сфері медичного обслуговування, службової діяльності, екології, обігу наркотичних засобів, психотропних речовин, їх аналогів або прекурсорів. Своєю чергою злочини, що вчиняються у сфері медичного обслуговування, можуть поділятися за такими напрямами: санітарна, лікувальна, косметологічна та науково-дослідна медицина. За кожним з цих напрямів злочини можуть поділятися на певні групи. Так, злочини, що вчиняються у сфері лікувальної медицини, за характером надання медичної допомоги можна поділити на ті, що вчиняються за безпосереднього надання медичної допомоги (профілактичні, діагностичні, терапевтичні втручання та втручання іншого характеру в організм пацієнта) i за опосередкованого надання медичної допомоги (відсутність втручання). За ознаками суб'єкта злочину залежно від рівня кваліфікації медичного працівника злочини можуть диференціюватися на ті, що вчиняються лікарями, молодшим медичним персоналом, лікарями-інтернами, науковими співробітниками. Залежно від обсягу повноважень злочини можна поділити на професійні та службові (вчиняються особами, які мають адміністративно-господарські та/або організаційно-розпорядчі обов'язки). За ознаками об'єкта злочину залежно від особи потерпілого злочини можуть поділятися на такі, що вчиняються відносно пацієнтів і сторонніх осіб і не потребують медичної допомоги (насильницьке донорство, проведення дослідів над людиною). Зазначені ознаки та виокремленні класифікаційні групи злочинів, що вчиняються медичними працівниками, безпосередньо стосуються формування методик їх розслідування, різних рівнів узагальнення. Вивчення й аналіз наукових праць, присвячених проблематиці криміналістичної класифікації, надають підстави стверджувати, що на сьогодні найбільш усталеною $\epsilon$ чотирирівнева структура, яка містить такі елементи: 1) міжвидові окремі криміналістичні методики розслідування (групи злочинів, класифіковані відповідно до їх групування в Особливій частині КК і на підставі криміналістично значущих ознак, притаманних декільком видам); 2) видові окремі криміналістичні методики (види злочинів, які розрізняються в розділах Особливої частини КК); 3) підвидові окремі криміналістичні методики розслідування (різновиди, виділені 3-поміж злочинів одного виду за криміналістично значущими ознаками); 4) комплексні окремі криміналістичні методики розслідування злочинів (комплекс різнооб' єктних, різнорідних злочинів, об'єднаних за криміналістичним критерієм). Предметом дослідження цих методик $\epsilon$ не вся злочинна діяльність, що охоплюється різнорідними злочинами, а тільки та їі частина, яка пов' язана з певною сферою діяльності, іï відповідними суб'єктами, формами співучасті тощо, тобто злочинна діяльність, обмежена криміналістичним класифікаційним критерієм [3].

Детальний аналіз Особливої частини Кримінального кодексу України дає змогу виділити норми про злочини, що вчиняються медичними й фармацевтичними працівниками, виявити характер їх співвідношення між собою, а також з іншими нормами про злочини проти життя і здоров'я особи.

Досить актуальним є питання щодо відмежування злочину, передбаченого ст. 131 КК України, від злочину, передбаченого ст. 130 КК України. За об'єктивною стороною наведені діяння мають спільні ознаки: це зараження особи вірусом імунодефіциту людини чи іншої невиліковної інфекційної хвороби, що $є$ небезпечною для життя людини. Проте $\epsilon$ й відмінність, а саме: ст. 131 КК України передбачає неналежне виконання медичним, фармацевтичним або іншим працівником своїх професійних обов'язків внаслідок недбалого чи несумлінного ставлення до них (тобто не виконання тих дій, які він за характером виконуваної роботи зобов' язаний був учинити). Звідси випливає відмінність суб'єктів викладених злочинів. Так, суб'єкт злочину, передбаченого ст. 130 КК України, є загальним [4, с. 267-268].

У пошуках шляхів подолання конкуренції між нормами ст. 131 КК України «Неналежне виконання професійних обов'язків, що спричинило зараження особи вірусом імунодефіциту людини чи іншої невиліковної інфекційної хвороби» та ст. 140 КК України «Неналежне виконання професійних обов'язків медичним або фармацевтичним працівником» бачимо, що в цих складах

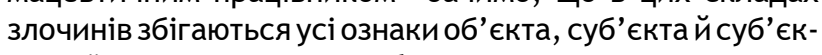
тивної сторони, а також обстановка вчинення злочину.

Проте ознаки діяння складу злочину, передбаченого ст. 140 КК України, є ширшими, ніж складу злочину, передбаченого ст. 131 КК України, тому норми, передбачені ст. ст. 131 і 140 КК України, перебуватимуть у конкуренції загальної й спеціальної норми.

Далі розглянемо норму, передбачену ч. 2 ст. 134 KК України «Незаконне проведення аборту», яка перебуває у конкуренції з нормами, передбаченими ст. 119 КК України «Убивство через необережність» та ст. $128 \mathrm{KK}$ України «Необережне тяжке або середньої тяжкості тілесне ушкодження». Як бачимо, у даних складах злочинів спільними є ознаки об'єкта й суб'єктивної сторони. Суб'єкт злочину, передбаченого ч. 2 ст. 134 КК України, - спеціальний, ним виступає виключно медичний працівник, який має спеціальну освіту. Специфічним $€$ також характер діяння (проведення незаконного аборту). Враховуючи вищезазначене, норма, передбачена ч. 2 ст. 134 КК України, є спеціальною щодо норм, передбачених ст. ст. 119, 128 КК України. [5, с. 485-486].

Норми, передбачені ст. ст. 132 і 145 КК України, також перебувають у конкуренції загальної і спеціальної норм. У цих складах злочинів спільними є всі ознаки об'єкта (окрім предмета злочину), суб'єкта, об'єктивної та суб'єктивної сторони. Відмежування злочинів, передбачених ст. ст. 132 й 145 КК України здійснюється за суб'єктивними й об'єктивними ознаками. Так, відомості про результати медичного огляду, наявність чи відсутність ВІЛ-інфекції в особи, яка пройшла медичний огляд, $є$ конфіденційними та становлять лікарську 
таємницю. Передача таких відомостей дозволяється тільки особі, якої вони стосуються, а у випадках, передбачених законами, також законним представникам цієї особи, закладам охорони здоров'я, органам прокуратури, слідства, дізнання та суду. Умови й порядок медичного огляду визначаються Правилами медичного огляду з метою виявлення ВІЛ-інфекції, обліку ВІЛ-інфікованих і хворих на СНІД і медичного нагляду за ними, які затверджені постановою Кабінету Міністрів України «Питання запобігання та захисту населення від ВІЛінфекції та СНІД» від 18 грудня 1998 р. № 2026 і Порядком добровільного консультування і тестування на ВІЛ-інфекцію (протокол), затвердженим наказом МO3 України від 19 серпня 2005 р. № $415[6,7]$.

у конкуренції кримінально-правових норм, що потребує розмежування складів злочинів, також перебуває ст. 139 КК України, яку слід відмежовувати від ст. 135 КК України «Залишення в небезпеці» та ст. 136 КК України «Ненадання допомоги особі, яка перебуває в небезпечному для життя стані».

В.М. Бурдіна, вважає, що норма, яка передбачена в ст. 135 КК України, $\epsilon$ спеціальною щодо норми, яка передбачена в ст. 139 КК України. Такий підхід обґрунтовується тим, що ст. 135 КК України передбачає кримінальну відповідальність за залишення без допомоги особи, яка перебуває в небезпечному для життя стані, і тим, що в ст. 139 КК України відсутня вказівка на те, що хворий повинен був перебувати в небезпечному для життя стані [8, с. 382]. Ми схиляємося до позиції В.Є. Ясеницького, котрий вважає, що у зазначених складах злочинів збігаються ознаки об'єкта й суб'єктивної сторони. Ознакою потерпілого від злочину, передбаченого ст. 139 КК України, є небезпечний для життя чи здоров'я стан особи. Ознакою потерпілого від злочинів, передбачених як ст. 135, так і ст. 136 КК України, $є$ небезпечний для життя стан, водночас указівка на такий стан особи міститься безпосередньо в диспозиціях відповідних норм. Суб'єкт злочину, передбаченого ст. 136 КК України, загальний, а ст. 135 КК України - спеціальний. Це особа, яка зобов'язана піклуватися про потерпілого, чи особа, яка сама поставила потерпілого в небезпечний для життя стан. У ст. 139 КК України суб'єкт злочину ще більш конкретизований: ним виступає медичний працівник. 3 огляду на це В.Є. Ясеницький вважає такий шлях кваліфікації дій медичного працівника, що не надав допомоги хворому, який перебував у небезпечному для життя стані, за відповідною частиною ст. 135 Кк України недоцільним. Аналогічно слід вирішувати питання й про кримінальну відповідальність медичного працівника, який, надаючи хворому медичну допомогу, вводить останнього в небезпечний для життя стан i не вживає жодних заходів для виведення потерпілого з такого стану. Так, якщо ставлення до можливих наслідків у винного характеризуватиметься необережною формою вини, відповідальність буде за ст. 140 КК України, якщо ж умисною - за нормою про умисне заподіяння шкоди здоров'ю або умисне вбивство [9].

Норма, передбачена ст. 140 КК України, буде спеціальною щодо норм, передбачених ст. ст. 119 або 128 КК України. Адже, як слушно зазначає А.Н. Язухін, не можна інкримінувати вбивство через необережність у зв'язку з професійно неправомірними діями хірурга, який порушив техніку операції, чи терапевта, який поставив неправильний діагноз, що призвело до смерті хворого [10, с. 73].

Ознаками основного складу злочину, передбаченого ст. 140 КК України, які не містять конкуруючі склади, $\epsilon$ суб'єкт (медичний або фармацевтичний працівник) і характер діяння, яке полягає у невиконанні чи неналежному виконанні професійних обов'язків [5].

Як зазначається в науковій літературі, здійснення кваліфікації за ознаками складу злочину - це науковий метод застосування кримінального законодавства. Використання такого методу допоможе порівняти вчинене суспільно небезпечне діяння із законодавчим визначенням подібного роду діянь не за випадковими, а за найбільш істотними й типовими ознаками, згрупованими за визначеною науковою системою - це кваліфікація за ознаками складу злочину [11].

Ще з радянських часів нормою вважається зіставлення порушень спеціальних правил у складах злочинів зі змішаною протиправністю з об'єктивною стороною складу злочину [12].

Застосовуючи конкретну банкетну диспозицію, необхідно встановлювати також і суб'єкта, як правило спеціального, і суб'єктивну сторону цього конкретного незлочинного правопорушення. На практиці аналіз цих елементів украй важливий як технічний спосіб, що дозволяє конкретизувати й остаточно визначити ознаки конкретного складу злочину.

Суспільні відносини, які конкретизуються за допомогою спеціальних нормативно встановлених правил, можуть бути як основними, так і додатковими об'єктами злочину, і цю обставину необхідно також враховувати у відмежуванні злочинів зі змішаною протиправністю від суміжних складів злочину.

Уже на етапі первинної кваліфікації (зокрема, на стадії порушення кримінальної справи) з розгляду правозастосовчого органу мають бути виключені ті обставини, що безпосередньо не пов'язані причинно-наслідковим зв'язкомзпорушеннямнормативновстановленихправил.

Здійснюючи кваліфікацію злочинів зі змішаною протиправністю, пов'язаних із порушенням нормативно встановлених правил, правоохоронний орган має враховувати як базовий елемент, необхідний для правильної юридичної оцінки, наявність безпосереднього взаємозв'язку всіх структурних елементів складу незлочинного правопорушення 3 усіма елементами складу злочину в цілому; водночас установлення елементів складу незлочинного правопорушення нормативно встановлених правил спеціальним суб'єктом має пріоритетне значення для правильної кваліфікації такого виду злочинів [13].

Висновки. Для кваліфікації злочинів передбачених ст. ст. 131, 132, 134, 139-145 КК України за суб'єктом злочину необхідно звертати увагу на те, що він $\epsilon$ спеціальним. Це медичні та/або фармацевтичні чи інші працівники (особи медичного персоналу: медичні сестри, фельдшери, працівники служби швидкої медичної допомоги). Кваліфікуючи злочин, передбачений ч. 1. ст. 131 КК України, потрібно виходити з того, що його об'єктивна сторона характеризується трьома обов'язковими ознаками: 1) діянням, яке виражене у неналежному виконанні медичним, фармацевтичним або іншим працівником своїх професійних обов'язків внаслідок недбалого чи несумлінного ставлення до них; 2) суспільно небезпечними наслідками у вигляді зараження 
особи вірусом імунодефіциту людини (ВІЛ) чи іншої невиліковної інфекційної хвороби, яка $\epsilon$ небезпечною для життя людини; 3) причинним зв'язком між зазначеним діянням і наслідками.

Кваліфікаційною ознакою злочину, передбаченого ч. 2 ст. 131 КК України, $є$ зараження двох або більше осіб. У разі кваліфікації злочину, передбаченого ст. 132 КК України, необхідно обов'язково встановити його предмет, яким виступають відомості про проведення медичного огляду осіб на виявлення зараження ВІЛ або іншої невиліковної інфекційної хвороби та його результати. Здійснюючи ж кваліфікацію цього злочину за об'єктивною стороною, слід враховувати, що вона полягає в розголошенні відомостей про проведення медичного огляду особи на виявлення зараження ВІЛ чи вірусом іншої невиліковної інфекційної хвороби, що $є$ небезпечною для життя людини, або захворювання на синдром набутого імунодефіциту (СНІД) та/або його результати.

Перш за все на кваліфікацію злочину, передбаченого ст. 139 КК України, впливає статус потерпілого, яким $\epsilon$ хворий. Особливістю кваліфікації ч. 1 ст. 139 КК України за об'єктивною стороною $\epsilon$ те, що остання характеризується бездіяльністю, яка проявляється в тому, що медичний працівник, який згідно з установленими правилами зобов'язаний надавати допомогу хворому, проте без поважних причин не робить цього. Кваліфікаційною ознакою злочину, передбаченого ч. 2 ст. 139 КК України, є спричинення смерті хворого або інших тяжких наслідків.

У разі здійснення кваліфікації злочину, передбаченого ч. 1 ст. 140 КК України, зважаючи на те що їі диспозиція $\epsilon$ банкетною, необхідно в кожному конкретному випадку встановлювати, які саме професійні обов'язки покладалися на винного та які з цих обов'язків не були виконані взагалі або виконані неналежним чином, а також вимоги яких саме нормативно-правових актів (наказів, інструкцій, указівок) ним порушено. Кваліфікаційною ознакою злочину, передбаченого ч. 2 ст. 140 КК України, є спричинення діянням тяжких наслідків неповнолітньому.

Кваліфікуючи злочин, передбачений ст. 141 КК України, за об'єктивною стороною, необхідно враховувати, що їй властиві такі ознаки: 1) дії у вигляді проведення клінічних випробувань лікарських засобів; 2) наслідки у вигляді смерті або інших тяжких наслідків; 3) причинний зв'язок між вказаними діями й наслідками.

Для кваліфікації злочину, передбаченого ст. 143 КК України, за об'єктивною стороною необхідно встановити такі його форми: 1) порушення встановленого законом порядку трансплантації органів або тканин людини (ч. 1 ст. 143 КК); 2) вилучення в людини шляхом примушування або обману їі органів або тканин (ч. 2 ст. 143 КК); 3) незаконної торгівлі органами або тканинами людини (ч. 4 ст. 143 КК); 4) участі у транснаціональних організаціях, які займаються вилученням у людини шляхом примушування або обману іï органів чи тканин з метою їх трансплантації або незаконною торгівлею органами або тканинами людини (ч. 5 ст. 143 КК). Для кваліфікації цього злочину необхідно першочергово приділити увагу його суб'єкту, оскільки він $є$ різним: за ч. 1 ст. 143 КК - спеціальний (особа медичного персоналу, яка, здійснюючи діяльність щодо трансплантації органів або тканин, порушує встановлений законодав- ством порядок її проведення); за ч. 2 ст. 143 КК - загальний; за ч. 3 ст. 143 КК - як загальний, так і спеціальний; за частинами 4 і 5 ст. 143 КК - загальний.

Під час здійснення кваліфікації за ст. 144 КК України необхідно звертати увагу на суб'єктивну сторону цього злочину, оскільки вона характеризується прямим умислом і спеціальною метою: використання людини як донора. Для ч. 3 ст. 144 КК спеціальною метою $є$ продаж крові.

Кваліфікація злочину, передбаченого ст. 145 КК України, за суб'єктивною стороною потребує встановлення змішаної форми вини, а саме умислу щодо діяння й необережності щодо його наслідків.

\section{Література}

1. Кримінальний кодекс України : науково-практичний коментар / Ю.В. Баулін та ін. Харків, 2007. 1184 с.

2. Кримінальний кодекс України : науково-практичний коментар / Ю.В. Баулін та ін. ; за заг. ред. В.В. Сташиса, В.Я. Тація. вид. 4-те, переробл. та доповн. Харків : Одісей, 2008. 1208 с.

3. Журавель В.А. Сучасні концепції формування окремих криміналістичних методик розслідування злочинів / В.А. Журавель. Вісник Національної академії правових наук України. 2007. № 2. С. 184.

4. Кримінальне право України. Особлива частина : підручник / Ю.В. Александров та ін. ; за ред. М.І. Мельника, В.А. Клименка. 3-тє вид., переробл. та допов. Київ : Атіка, 2009. 744 c.

5. Ясеницький В.Є. Кваліфікація злочинів, що посягають на права пацієнта. Актуальні проблеми держави $i$ права. 2005. С. 485-486.

6. Постанова Кабінету Міністрів України «Питання запобігання та захисту населення від ВІЛ-інфекції та СНІД» від 18 грудня 1998 р. № 2026. Офіційний вісник України. 1998. № 51. Ст. 42.

7. Наказ Міністерства охорони здоров'я України «Про удосконалення добровільного консультування і тестування на ВІЛ-інфекцію» від 19 серпня 2005 р. № 415. Офіційний вісник України. 2005. № 48. Ст. 112.

8. Бурдін В.М. Особливості кримінальної відповідальності лікарів за ненадання допомоги хворому. Проблеми державотворення і захисту прав людини в Україні : матеріали Х регіон. наук.-практ. конф. С. 382.

9. Ясеницький В.Є. Кваліфікація злочинів, що посягають на права пацієнта. Актуальні проблеми держави $i$ права. 2005. С. 486.

10. Язухин А.Н. Спорные вопросы квалификации преступных деяний медицинских работников. Вопросы совершенствования уголовно-правового регулирования. Свердловск, 1988. С. 103.

11. Куринов Б.А. Научные основы квалификации преступлений : учебное пособие для вузов / Б.А. Куринов. Москва : Издательство МГУ, 1984. 181 с.

12. Советское уголовное право. Часть особенная / под ред. М.И. Ковалева. Москва : Юрид. лит. 1983. 576 с.

13. Гринь О.Д. До питання про значення окремих елементів складу злочину зі змішаною протиправністю в процесі кваліфікації. Боротьба з організованою злочинністю і корупцією (теорія і практика). 2011. № 25. С. 225.

Шопіна Ю. О., аспірант кафедри кримінального права Національної академії внутрішніх справ, головний спеціаліст Департаменту юридичного забезпечення міністерства внутрішніх справ України 